\section{Endoscopic clip tamponade of bleeding: a novel adjunct technique for endoscopic mucosal resection}

Endoscopic mucosal resection (EMR) of large nonpolypoid neoplasms of the colon may be complicated by immediate, early (first 24 hours), or delayed bleeding [1]. Endoscopic hemostasis of immediate bleeding can be achieved by epinephrine injection, cauterization of the bleeding site, and mechanical tamponade by resnaring the stalk or deployment of a band, clip, or detachable snare [1 -4$]$.
Inadvertent entrapment of tumor tissue during clip deployment to control immediate bleeding after snare resection during piecemeal EMR may interfere with further snare resections and require surgery, as highlighted by patient \#1 (৫ Table 1; $\bullet$ Fig. 1). This problem could be easily overcome using a novel technique of "endoscopic clip tamponade" (ECT) for 3 minutes to control bleeding followed by reopening of the clip and completion of the EMR procedure, as described in patients \#2-\#4 (๑ Table 1 ).

Piecemeal EMR was undertaken with a stiff snare after injection of indigo carmine solution into the submucosa to lift the lesion ( $\bullet$ Fig. 2 a). With this technique, bleeding after first resection was controlled using the technique of endoscopic clip tamponade ( $\bullet$ Fig.2b). After the bleeding site was localized with a water jet, a clip with a reopening function (Resolution Clip, Boston Scientific, Natick, Massachusetts, USA) was applied immediately to the bleeding site. If bleeding persisted, the clip was reopened and reapplied more accurately to achieve hemostasis.

Table 1 Outcome of endoscopic mucosal resection (EMR) procedures in four patients with varying methods of endoscopic hemostasis employed for management of bleeding.

\begin{tabular}{|lllllll}
\hline $\begin{array}{l}\text { Case } \\
\text { number }\end{array}$ & $\begin{array}{l}\text { Age, years; } \\
\text { sex }\end{array}$ & Site; size, $\mathbf{c m}$ & $\begin{array}{l}\text { Method of endoscopic } \\
\text { hemostasis }\end{array}$ & Outcome of EMR & Surgery & Pathology \\
\hline 1 & $77 ; \mathrm{F}$ & Cecum; 5 & Clip deployment & $\begin{array}{l}\text { Aborted during first } \\
\text { colonoscopy; failed dur- } \\
\text { ing second colonoscopy }\end{array}$ & $\begin{array}{l}\text { Right hemi- } \\
\text { colectomy }\end{array}$ & $\begin{array}{l}\text { Tubulovillous adenoma with } \\
\text { high grade dysplasia }\end{array}$ \\
\hline 2 & $57 ; \mathrm{F}$ & Rectum; 5 & $\begin{array}{l}\text { Clip tamponade } \\
\text { (2 piecses) }\end{array}$ & No & Tubulovillous adenoma \\
\hline 3 & $44 ; \mathrm{M}$ & Sigmoid colon; 5 & Clip tamponade & $\begin{array}{l}\text { Successful } \\
\text { (4 pieces) }\end{array}$ & No & $\begin{array}{l}\text { Villous adenoma with foci } \\
\text { high grade dysplasia }\end{array}$ \\
\hline 4 & $52 ; \mathrm{M}$ & Cecum; 4 & Clip tamponade & $\begin{array}{l}\text { Successful } \\
\text { (5 pieces) }\end{array}$ & Nubulovillous adenoma with \\
focal high-grade dysplasia
\end{tabular}
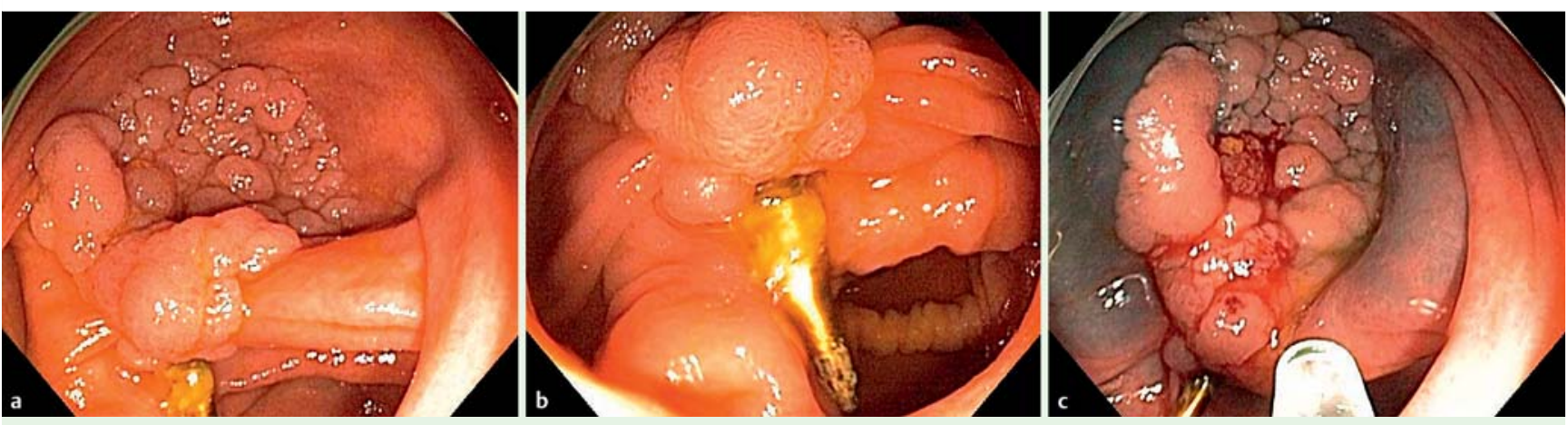

Fig. 1 Endoscopic appearances of the procedure in patient \#1 in which clip deployment for hemostasis resulted in a failed endoscopic mucosal resection (EMR) showing: a a 5-cm laterally spreading granular tumor in the cecum; b clip tethering of the polyp to the wall; $\mathbf{c}$ failed lifting of the lesion after submucosal injection.
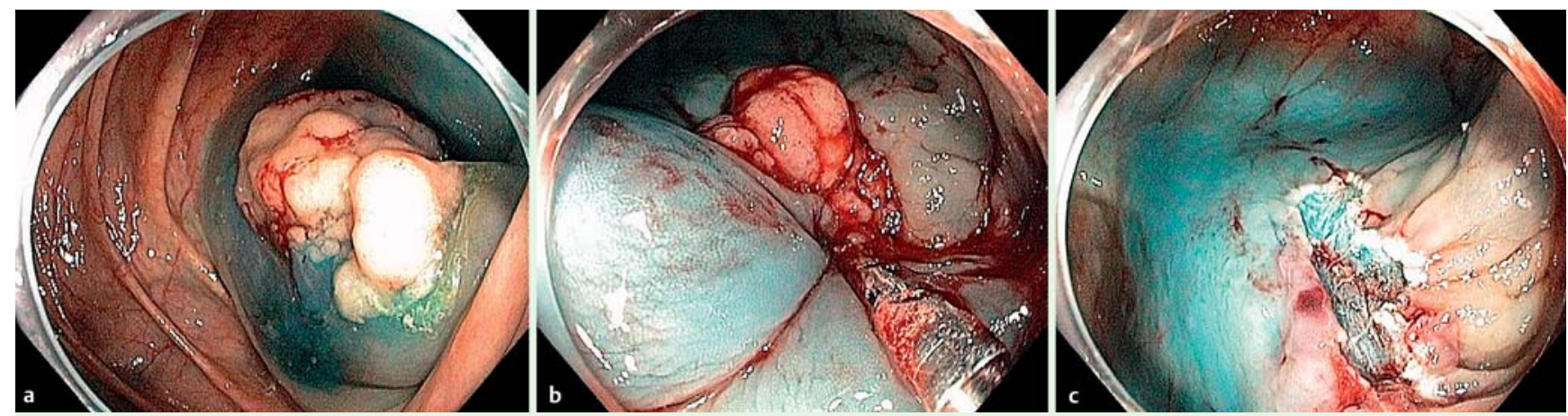

Fig.2 Endoscopic appearances in a patient who underwent clip tamponade that successfully achieved hemostasis showing: a successful lifting of the lesion with submucosal injection; b endoscopic clip tamponade of bleeding; c completion of the endoscopic mucosal resection (EMR). 
Once hemostasis had been confirmed, the clip was held in place for a minimum of 3 minutes. It was then reopened and removed from the operating field. Resection of the remaining polyp was completed ( $\bullet$ Fig. $2 \mathbf{c}$ ), and the EMR defect was closed with clips ( $\bullet$ Video 1 ).

We demonstrated that endoscopic clip tamponade controlled arterial bleeding and allowed successful completion of the EMR. Hasty deployment of clips to control arterial bleeding prior to completion of the resection may preclude subsequent endoscopic resection and require surgery.

\section{Video 1}

A case showing hemostasis being achieved by clip tamponade following acute post-polypectomy bleeding.

Endoscopy_UCTN_Code_TTT_1AQ_2AZ

\section{W. C. Chen', D. M. Maru²,}

\section{S. C. Abraham², D. Tan², G. S. Raju}

${ }^{1}$ Department of Medicine, The Methodist Hospital, Weill Cornell Medical College, Houston, Texas, USA

2 The University of Texas MD Anderson Cancer Center, Houston, Texas, USA

\section{References}

1 Ginsberg G. Risks of colonoscopy and polypectomy. Tech Gastrointest Endosc 2008; 10 : 7-13

2 Raju GS, Gajula L. Endoclips for GI Endoscopy. Gastrointest Endosc 2004; 59: 267-279

3 Raju GS, Kaltenbach T, Soetikno R. Endoscopic mechanical hemostasis of GI arterial bleeding (with videos). Gastrointest Endosc 2007; 66: 774-785

$4 \mathrm{Kim}$ SH, Moon JS, Youn YH et al. Management of the complications of endoscopic submucosal dissection. World J Gastroenterol 2011; 17: 3575-3579
Bibliography

DOI http://dx.doi.org/ 10.1055/s-0032-1326280

Endoscopy 2013; 45: E104-E105

(c) Georg Thieme Verlag KG

Stuttgart · New York

ISSN 0013-726X

\section{Corresponding author}

\section{G. S. Raju, MD}

The University of Texas MD Anderson

Cancer Center

1515 Holcombe Blvd, GI Division - Unit 1466 Houston, TX 77030-4009

USA

Fax: +1-713-694-5398

gsraju@mdanderson.org

\section{Competing interests: None}

